\title{
Institutional Racism in Enforcing Immigration Law
}

\author{
DORIS MARIE PROVINE*
}

\section{ABSTRACT}

The United States is committed to aggressive efforts to remove unauthorized immigrants while honoring its commitment to race neutrality. Yet immigration enforcement has disproportionately targeted Mexicans and Central Americans. The racial bias can be found at both the federal and local levels, where local police are becoming increasingly involved in locating unauthorized immigrants. The local example featured here is Arizona because of its historical relationship with Mexico and its enthusiasm for immigration enforcement. I find that the current mix of federal and local enforcement discriminates racially through profiling, hyper-surveillance, abusive stops, problematic searches, and unwarranted detention.

Key words: immigration enforcement, ethno/racial profiling, pretextual stops, devolution, plenary power.

\section{RESUMEN}

Estados Unidos se ha comprometido a realizar importantes esfuerzos para sacar a los inmigrantes no autorizados de su territorio, al mismo tiempo que mantiene su compromiso con la neutralidad racial; sin embargo, la institución encargada de hacer cumplir las leyes de inmigración se han ensañado de manera desproporcionada contra los mexicanos y centroamericanos. El prejuicio racial se puede encontrar tanto en el nivel federal como en el local, donde la policía cada vez se involucra más en ubicar a los inmigrantes no autorizados. El ejemplo que en este artículo analizamos es el de Arizona, debido a su relación histórica con México y a su vehemencia en la persecución de inmigrantes. Se muestra cómo el trabajo conjunto de las agencias locales y federales resulta racialmente discriminatorio debido a los perfiles que elabora, así como por la vigilancia exagerada, los retenes abusivos, los registros problemáticos y las detenciones arbitrarias.

Palabras clave: agencias de regulación de la inmigración, perfiles etnorraciales, detenciones pretextuales, descentralización, poder plenario.

\footnotetext{
* Professor Emerita, School of Social Transformation, Arizona State University, marie.provine@gmail.com
} 


\section{INTRODUCTION}

Race and immigration law are -perhaps inevitably- intertwined. The desire to separate people by race, and sometimes by religion, has often animated campaigns for exclusionary laws. These campaigns are sometimes successful, as in the adoption of what became known as the Chinese Exclusion laws in the late nineteenth century. Californians ardently campaigned for these laws, designed to discourage Chinese migrants from settling or remaining in the United States. Supporters justified these laws on the basis that Chinese people are inherently incapable of assimilation into the U.S. American way of life. The U.S. Supreme Court bought this logic and upheld the legislation in a series of precedent-setting cases (see, for example, Park, 2004; Chin, 2005).

Over time, the role of race and racism in immigration law has changed. Laws that explicitly target particular groups for inclusion or exclusion can no longer be justified on eugenic grounds (Gomez, 2007). Yet immigration laws and policies that leave room for race to play a significant role in enforcement are not only tolerated, but often embraced by immigration restrictionists (Sinema, 2012). They typically feature a large measure of discretion for the front-line officials who determine when surveillance occurs and what cases get priority. Safeguards to prevent abuses are generally lacking.

The enduring relationship between race and immigration law can be traced to popular fears and anxieties about racial "others" and the fragility of national allegiances, which depend on a sense of fellow feeling among "members" (Omi and Winant, 1994; Bosniak, 2006; Kanstroom, 2007). As Benedict Anderson suggests, one's membership in a national body is in reality "an imagined community" of people who believe that they belong together. This abstract sense of membership leaves a lot of room for the exclusion of people who seem different, and perhaps not suitable for assimilation (Anderson, 1983; Kanstroom, 2007; Zolberg, 2006). It is thus not surprising that much of the pressure for exclusion comes from citizens themselves, not from the top, where commercial interests and international diplomacy may dictate a more cosmopolitan approach. In Europe, for example, populist parties have made sharp restrictions on immigration a central plank in their platforms.

The question is not so much why race matters to citizens who feel threatened by rapid demographic change, but rather how the law adapts to racial anxieties. In a time when race-neutral rules have found favor, how does racial disadvantage persist? This essay offers a two-part explanation, based on the U.S. experience. Latinos in the United States, particularly immigrants of Mexican and Central American origin, have been disproportionately targeted for deportation (Provine and Doty, 2011). The pattern is evident in popular stereotypes about immigrants, in the spending and 
construction that are taking place on the southern border with Mexico, and in the racial/ethnic patterns associated with deportation.

This essay first details the role that race plays in federal immigration-enforcement operations, and then turns to the local level, where, under a federal policy of devolution, local law enforcement agencies are being asked to assist in enforcing federal immigration law. Arizona's participation is highlighted here because the state stands out for the enthusiasm with which it has embraced deportation as the solution to unauthorized residence and for its effort to supplement federal enforcement with its own laws and policies. The mix of federal, state, and local law and policy that I describe here institutionalizes racism by facilitating ethno-racial profiling, hyper-surveillance, abusive stops, problematic searches, and unwarranted detention of suspected unauthorized immigrants. The targets of these actions are disproportionately Latinos because U.S. Americans, including members of the law enforcement community, have been conditioned to see the problem of unauthorized entry and residence in racial terms, as a Mexican and Central American phenomenon (Chavez, 2008; Ngai, 2004). Ironically, those who demand more enforcement invariably ignore these problems in order to focus on the illegality of the immigrant's actions in remaining without authorization. The much more significant story in a nation that honors the rule of law is the failure of government to adhere to its own high standards.

\section{The Federal Government and Racialized Immigration Enforcement}

The actions of the federal government would indicate to any casual observer that the nation's primary immigration concern is with illegal entry from Mexico. For over a decade the porosity of the southern border has been the focus of contentious rhetoric and continually increasing spending on personnel and equipment. Though visa overstayers are estimated to make up approximately 40 percent of the unauthorized population resident in the United States, their presence has provoked much less attention, much less outrage from politicians and the public, and much less spending.

In one sense, it is not surprising that the spotlight has focused on Mexicans and persons from further south who have illegally crossed the southern border. This border was for a long time relatively open, in deference to border communities and U.S. employers desiring temporary Mexican labor (Kang, 2010; Ngai, 2004). Past porosity and the historic relationship between the two nations have set the stage for continued illegal immigration from Mexico because would-be migrants rely upon their connections with already-resident family and friends as a form of social capital (Massey, Durand, and Malone, 2002). The problem of illegal entry or re-entry is exacerbated by the dif- 
ficulty of gaining work or visitation visas in Mexico and by the extremely lengthy wait requirements for legal immigration from Mexico.

The upshot is that Mexicans constitute slightly over half of the unauthorized population within U.S. territory, giving law enforcement some reason to focus on people who appear to them to be from Mexico or Central America. To the extent that this logic informs enforcement, however, the federal government, through the weight of its authority, paints the face of illegal immigration as Mexican or Central American. Lost in the translation of policy into practice is the reality that persons without legal status can be found in all colors and among all classes and every nationality.

\section{Federal Immigration Stops and Searches:} The Ethno-racial Dimension

The hardening of the federal position on immigration from Mexico began with Operation Gatekeeper and Operation Hold-the-Line in the mid-1990s. These programs fortified the border in populated areas, while relying on the inhospitable desert and the reality of dehydration and death to discourage immigration from more remote areas (Nevins, 2002; Doty, 2010). Over 85 percent of U.S. Border Patrol agents are currently deployed along the southern border, and they have been supplemented by the National Guard, federal investigators, and federal drug-control agents (Haddal, 2010). Expensive technologies (drones, satellites, remote sensors, and aircraft) have also been deployed, and a massive construction project to build a wall between the two countries is underway.

Federal enforcement priorities at the southern border pay little heed to basic rights or dignity (see Danielson, 2013). In November 2013, for example, the head of U.S. Border Patrol announced that his agents would continue to use deadly force against rock-throwers and assailants in vehicles despite the recommendation to end these practices in a government-commissioned review (Spagat, 2013). That review was provoked by the shooting deaths of 20 people by Border Patrol since 2010, including an unarmed Mexican who died from stun gun wounds at San Diego's San Ysidro port of entry.

The courts have not proven effective in protecting the rights of migrants to constitutionally guaranteed due process. Federal judges in districts on the southern border have seen their courtrooms inundated with people charged with federal crimes under Operation Streamline, a program to prosecute those caught crossing the border. The process begins with apprehensions of people caught crossing illegally by the Border Patrol or another policing authority. Those caught are held in detention 
until time can be found for a court hearing. Some will not be charged because the court cannot handle the caseload. So detainees wait, not knowing whether they will be among those criminally charged or not. Those charged are arraigned and processed in groups of up to 10 at a time. They face a lengthy prison term unless they plead guilty to the crime of unauthorized entry, which gives them a criminal record. The criminal record makes them felons, which in turn helps to justify stronger enforcement measures against "dangerous" criminals (Trevizo, 2013).

Federal activities inside the country have also been ramped up in recent years in ways that tend to target Latinos. For a time, federal agents staged highly publicized workplace raids, mostly directed against immigrants from Mexico and Central America working in meatpacking and other physically exhausting low-wage jobs. The usual charge was using false identity documents. This policy included some legally indefensible actions against immigrants, such as the federal raid of a meatpacking plant in Postville Iowa, where the U.S. Supreme Court handed down a unanimous opinion rebuking prosecutors for over-charging the largely Guatemalan defendants in order to get guilty pleas (Flores-Figueroa v. US, 2009; Camayd-Freixas, 2008). Workplace enforcement continues, but has become less public. Federal immigration agents now audit company records, leading employers to fire workers with questionable legal status.

The National Fugitive Operations Program offers another route to deportation that tends to target Latinos. Created in 2003, the program's mandate was to locate, arrest, and remove immigrants with old deportation orders, focusing particularly on fugitives who threaten national security or endanger communities. That requirement was soon dropped as the size and scope of the program steadily increased. Now 129 enforcement teams operate across the country, often conducting house raids that involve questioning the legal status of the entire household and arresting anyone who cannot prove their legal status (ICE, 2013).

Researchers have found a decided tendency of these teams to ignore Constitutional requirements against breaking into homes without legal authority, searching without a warrant, seizing innocent people, and racial profiling of Latinos. In two locations studied by researchers from the Benjamin Cardozo School of Law, collateral arrests of Latinos outstripped targeted arrests by over 20 percent, suggesting that non-targeted arrestees were stopped and questioned on the basis of appearance alone (Chiu et al., 2009). An analysis by the Migration Policy Institute found that over 70 percent of those apprehended had no prior criminal convictions (Mendelson, Strom, and Wishnie, 2009).

Enhanced federal enforcement efforts have also targeted legal permanent residents in a way that tends to focus on Latinos. The context includes action by the U.S. Congress to greatly increase the number of crimes resulting in deportation of legal 
permanent residents, and, at the executive level, an increased commitment to enforcing this policy. The law provides no exceptions for the number of years that have passed since the crime was committed or the circumstances surrounding the conviction. Until recently, there was no obligation on anyone's part to inform defendants that negotiating a plea of guilty to achieve a lesser sentence or fine could result in deportation (Padilla v. Kentucky, 2010).

According to a Human Rights Watch study (2009), Mexican-origin residents have been vastly over-represented in the pool of persons deported for past criminal convictions. The report found that these legal permanent residents made up 78.2 percent of the total over the 10-year period the group studied. Although the Criminal Alien Program has been advertised as a means of removing dangerous felons from U.S. neighborhoods, only 2 percent of those detained were charged with felony offenses; 98 percent of the cases involved only misdemeanors (Gardner and Kohli, 2009).

\section{Federal Partnerships with Local Police}

As it increased its own interior-enforcement efforts, the federal government for the first time created formal, on-going immigration-enforcement partnerships with local police, a policy that casts local police as a "force multiplier" to enhance federal enforcement (Decker et al., 2011). Congress created a legal structure for such partnerships in 1996 within the Illegal Immigration Reform and Immigrant Responsibility Act. Under an arrangement stipulated there, cooperating agencies sign a formal memorandum of understanding to train local officers either to assist in the identification of arrested suspected unauthorized immigrants while they are booked in jail, or to question and detain such immigrants in the course of street patrol. The program, which became known as "287(g)" after its legislative moorings, drew little interest at first, but some law-enforcement organizations began to sign on after the 2001 terrorist attacks on the World Trade Center and the Pentagon. Pressure on local law enforcement to become involved increased with a 2003 Justice Department decision to add civil immigration data, such as outstanding deportation orders, to databases that local police use in pursuing criminal suspects across state lines (Gladstein et al., 2005). Federal spending was also increased to embed more federal immigration agents into local departments.

Although these partnerships have been touted as a way to control serious crime, the evidence is strong that the real priority has been to increase the numbers of immigrants detained and deported, which are now at historic highs. The General Accounting Office found in a 2009 report that some police departments were routinely 
using their 287(g) authority on people arrested for minor traffic violations (GAO, 2009; and see Shahani and Greene, 2009: 16). A 2011 report by the Migration Policy Institute found that half the cases resulting in deportation involved low-level misdemeanor or traffic cases. Federal officials have ignored such evidence of widespread racial profiling and pretextual stops. Failure to safeguard against these abuses has led to recommendations that the program be cancelled from various observers, including the Inter-American Commission on Human Rights, an arm of the Organization of American States (Semple, 2011).

The 287(g) Program, however, has been overshadowed by a much more comprehensive and far-reaching initiative: Secure Communities. The concept behind Secure Communities is sharing data: local jails make all their booking data available to the federal government, and in return they receive information on immigration violators and criminal matters. The information sharing facilitates federal imposition of "holds" that bar the release of arrested persons for at least 72 hours, in order to determine if deportation might be warranted. This mandatory program has been implemented without safeguards against illegal arrests (Kohli, Markowitz, and Chavez, 2011).

There are already indications that Secure Communities, like previous federal programs designed to focus on dangerous offenders, is not achieving its ostensible goals. A study by the Arizona Republic found that, nationwide, 60 percent of those deported were either low-level criminals or had no criminal record at all. In Arizona, the rate was 66 percent, mostly thanks to the efforts of Maricopa County sheriff's office, which leads the nation in both the number of (almost entirely Latino) immigrants arrested and in the number deported (Gonzales, 2011; Hensley, 2013).

Nor is the federal government's own practice reassuring. In 2012, as in every previous year during the Obama and recent Bush administrations, record numbers of people were approved for deportation. Over 400000 people were deported that year, many with deep roots in the United States. Since then the number has decreased only slightly. Despite an avowed policy of concentrating resources on serious criminal violators, the record is of escalating deportations made up mostly of residents with little or no involvement in crime.

\section{Racialized Immigration Enforcement at the Local LeVel: The Case of Arizona}

The federal government's initiatives for devolving immigration enforcement authority to the local level, at first voluntary through the $287(\mathrm{~g})$ program and then mandatory with Operation Secure Communities, have come without regulatory strings that would 
prevent racial profiling, pretextual stops, or other forms of racialized policing. This is a significant omission. Policing is highly discretionary work with ample opportunities for stereotypes of various kinds to find their way into enforcement decisions (Brown, 1988; Chambliss, 1994). The dangers of racially biased immigration policing are particularly great in a state like Arizona, where geography, history, and changing demographics tend to fan fears of an "invasion" of poor Mexicans who will deplete government resources and impoverish the state (Chavez, 2008).

\section{Latino Immigrants in Arizona}

According to data from the 2010 U.S. census, Arizona is the second-fastest growing state in the nation. Latinos now make up nearly 30 percent of state residents, up from just over 25 percent in 2000. Much of this growth has occurred in small towns outside of the Phoenix metropolitan area, which remains, by far, the largest urban concentration of Latinos in the state. Unauthorized residents, primarily of Mexican origin, make up about 9 percent of the population and 10 percent of the state's labor force (Passel and Cohn, 2010).

A significant Latino presence in Arizona is not new. The United States acquired part of the Arizona territory in 1853 as part of the Gadsden Purchase. Mexicans residing in the new territory were entitled to U.S. citizenship and were officially declared "white" in order to satisfy naturalization requirements in place at that time. Neither the formal status of citizenship nor their legal whiteness, however, eliminated systematic discrimination against them by Anglos, who increased their dominance as their numbers increased (Gomez, 2007).

During the 1910 Mexican Revolution, large numbers of Mexican citizens moved to Arizona to escape the violence in their country and to seek employment in the booming mining industry. Their labor, however, earned less than half the Anglo wage (Gordon, 2001). During harsh economic times, immigration raids against Latinos were common. Local law enforcement removed over 1000 foreign workers from Bisbee, Arizona in 1917, sending them in boxcars to the New Mexico desert (University of Arizona, 2011). During the Depression of the 1930s, many Mexican and MexicanAmerican workers and their families were deported from Arizona by the federal immigration service.

The situation eventually stabilized in Arizona, which remained racially segregated by law until the 1950s, when courts began to overturn statutes and ordinances mandating segregation in schools and public services. This period also spelled the end of restrictive covenants in deeds of real property designed to keep the races apart. 
The state began to enter a newly restrictive era, however, when the federal government closed popular urban crossing points in California and Texas in the 1990s. Determined migrants began crossing through the desert regions of Arizona much more frequently. The changes were alarming to many and calls to "do something" about the illegal flow of people into the state became increasingly frequent.

Local law enforcement officials were also under pressure from local and federal sources to respond more actively to the presence of residents without legal status. In 1997 the Chandler police, working with federal immigration officials, conducted a week-long series of immigration raids that generated national attention. In what became known as the "Chandler Roundup," officials stopped and questioned dozens of Latinos on the basis of their physical appearance, leading to unjustified arrests and a successful lawsuit based on civil-rights violations (Romero, 2006; Romero and Serag, 2004). Despite this victory, the possibility of deportation was becoming a real risk in many minds. Scholars reported, for example, that victims of domestic violence had become afraid to contact local police for fear of deportation of a loved one or other immigration-related consequences (Menjivar and Salcido, 2001).

The heritage of discrimination and lack of educational and economic opportunities, in tandem with police surveillance and intimidation, have had profound effects. The threat of deportation affects citizens as well as non-citizens because many families and friendship groups are of mixed legal statuses. The long history of discriminatory treatment has also had an impact on the development of strong Latino leadership in the state, which in turn has affected Latino turnout at elections. Inability to strike back forcefully at the polls has made this population vulnerable to hostile legal initiatives sponsored by politicians ready to cash in on the fears and antipathies of white voters unprepared for demographic change (see, for example, Singer, Hardwick, and Brettell, eds., 2008; Zúñiga and Hernández León, eds., 2005).

\section{The Rise of State-level Anti-immigrant Legislation and Policing}

Within Arizona, demands for a change in the enforcement status quo started with complaints of federal inaction, but soon shifted toward proposals for state legislation to discourage unauthorized immigrants from remaining in the state. This movement began with legislation requiring the use of English in government transactions and restricting welfare or public benefits to those who could prove legal status. Then, beginning in 2004, voters embraced a series of initiatives to eliminate rights that unauthorized residents had long enjoyed, including in-state tuition for those satisfying residency requirements. In 2007, the legislature approved the denial of bail to unauthorized 
immigrants accused of serious crimes. In 2008 it adopted an employer sanctions law to punish employers who knowingly hire unauthorized workers.

Around 2005, encouraged by the pervasive anti-immigrant atmosphere, Maricopa County sheriff Joseph Arpaio began to undertake workplace raids and "crime suppression sweeps" in predominantly Latino neighborhoods in the Phoenix metropolitan area. The raids, marketed to the public as efforts to remove criminals, in reality were aimed at detecting and deporting unauthorized residents. Day laborers, many of whom are Latinos, have also felt the brunt of aggressive law enforcement. Some municipalities have prohibited them from congregating in public areas to offer labor services. Law enforcement agencies in Arizona have occasionally enforced these ordinances, arresting Latino men who, despite being U.S. citizens, are subjected to stops on the basis of their use of language, their attire, or choice of location (Varsanyi, 2008). Checkpoints have become another form of intimidation against Latino workers and their families, as these operations tend to be launched only in immigrant communities or work areas during regular commuting hours.

Such law-enforcement initiatives remind Latino residents, regardless of their immigration status, of the power that police and sheriff deputies have over their lives. The Sheriff Arpaio's continued popularity and the stream of anti-immigrant rhetoric and legislation from the state legislature reinforce a pervasive sense of intimidation. For example, a study of Latina immigrant women's sense of safety in Phoenix and Tucson revealed widespread fear of leaving home, even among women with secure legal status; Sheriff Arpaio and his deputies were cited more often than anyone as the source of this pervasive sense of fear (McDowell and Wonders, 2010).

\section{Arizona's Employer Sanctions Law}

Arizona's Legal Arizona Workers Act, commonly referred to as the state's "employer sanctions law," prohibits businesses from knowingly or intentionally hiring an "unauthorized alien." The law also requires employers in Arizona to use the E-Verify system, a free web-based Department of Homeland Security service to verify the employment authorization of all new employees. While business owners initially opposed the measure in court, enforcement practices soon revealed that the real target of this law was unauthorized workers. Only two companies have been penalized since the sanctions law entered into effect in 2008. One was Waterworld, an amusement park that had already closed and filed for bankruptcy before any determination of wrongdoing, and the other was a sandwich shop that was ordered to close its doors for only one day: Thanksgiving. The employer sanctions law has instead been used to justify employ- 
ment-site raids against businesses believed to hire undocumented immigrants. Most cases arise from tips from disgruntled employees or managers within the companies themselves. Sometimes citizens report seeing "illegals" on the business' premises, their suspicions aroused by hearing "Mexican" music or Spanish being spoken between staff members. The Maricopa County Sheriff Office and the county attorney have responded to these reports as credible enough to open official investigations.

Details of arrests in the Waterworld case, gleaned from case files, indicate problematic police behavior (Provine and Sanchez, 2012). ${ }^{1}$ In one instance, although there was no public stop and search, highly intrusive surveillance was utilized. Undercover officers followed five Latina employees suspected of being undocumented to and from work for several days even before their employment eligibility was verified. The women were shadowed as they drove to their children's schools, visited relatives, shopped for groceries, and attended church. The officers justified their intrusive surveillance as necessary to ensure their own safety.

In another instance, the police stop clearly seems to have been unnecessarily violent. Celia Alvarez, a janitor and mother of four U.S.-born children, was arrested when sheriff's officers burst into the landscaping firm she had worked at for five years, acting on a tip from a "concerned" supervisor who allegedly reported that the company hired undocumented workers. Alvarez described in court testimony how deputies wearing ski masks entered the building, warning the occupants they were looking for "illegal aliens." The officers found Alvarez hiding under a table, "lifted her off her feet, and slammed her face into a wall," causing injuries to her face, jaw, and teeth. Another officer allegedly hit her with a clipboard for trying to speak to another detainee.

A third lawsuit involved a stop and detention based on ethno-racial profiling, followed by a gratuitously humiliating detention. Julian Mora, one of Alvarez's coworkers, was detained during the same operation in which she was arrested. Mora, a legal permanent resident, was on his way to work when two Maricopa County sheriff's vehicles blocked his progress. The deputies arrested Mora and his son, a U.S. citizen, who was accompanying him. The officers handcuffed them and held them without explanation for three hours. Mora, a diabetic, was not allowed to use the restroom, but was eventually granted permission to urinate by the side of a truck as deputies watched. He and his son were eventually released. The lawsuit that the American Civil Liberties Union filed on the Moras's behalf alleges that father and son were stopped because officers interpreted Julian Mora's skin color and the denims he was wearing as indicators of illegality.

\footnotetext{
${ }^{1}$ The three cases discussed below, as well as details regarding stops under Arizona's human smuggling law were compiled by Dr. Gabriella Sanchez, who was a co-author with me of an article published in Provine and Sanchez (2012).
} 


\section{Policing Human Smuggling through Stops}

\section{And Prosecution of Smuggled Latino Immigrants}

A similar pattern of ethno-racial profiling can be seen in the enforcement of Arizona's unique human-smuggling statute. In 2005, in response to public concern over increased smuggling of drugs, weapons, and humans through the state, the Arizona legislature approved an anti-human trafficking law. The statute established prison terms for the men and women involved in the transportation of people known or presumed to lack legal status to be in the state. It also expanded the definition of human smuggling, allowing for the detection and arrest of those suspected to be engaged in smuggling activities. With this vague definition, Arizona officials began to prosecute undocumented immigrants entering the country with the assistance of a human smuggler or coyote. In short, "smugglees" became human smugglers under Arizona law.

Over 1000 undocumented Latino immigrants, many of whom had been victims of border violence, had been successfully prosecuted under the statute by mid-2011. The prosecutions have continued despite legal challenges. The volume of cases is great enough to create backlogs in court processing. An immigrant charged with conspiracy to be smuggled into Arizona can expect to wait an average of three months in custody before the case will be heard; state law prevents pre-trial release. If convicted, these people face deportation as well as possible federal criminal charges if their presence in the country is determined to be the result of an illegal re-entry.

The importance attached to the issue of human smuggling has justified aggressive anti-smuggling interventions in predominantly low-income Latino sections in the Phoenix metropolitan area. In March 2009, for example, a human-smuggling investigation led to the stop and detention of Refugio Serna, who was handcuffed and driven around the cities by state police officers for 11 hours. Serna, a U.S. citizen and an employee of the Department of Homeland Security, was picking up his brother-inlaw at a parking lot in a predominantly immigrant neighborhood in Phoenix. The police report cited Serna's "bold and very confident demeanor while driving a truck [and] playing Mexican music very loud" as sufficient probable cause for stopping and questioning him.

A detective handcuffed Serna and put him in the back of a police vehicle, alleging concerns for his own safety. Serna spent the rest of the day handcuffed in the police vehicle. The officers told him that he was not under arrest, suggesting that he could get out and go home if he so desired as they drove through a desolate area. Serna's frustration was evident in his statements to court investigators. They reveal the embarrassment and pain he felt while the officers paraded and questioned him in public, especially when he was later ridiculed in front of his very concerned family and 
neighbors. He was forced to resign from his job as a result of the criminal investigation launched against him, though no charges were filed (Provine and Sanchez, 2012).

The human smuggling law has also led to police roadblocks and patrols that engage in questionable stops in areas designated as "human smuggling corridors." Sheriff's deputies frequently conduct "smuggling interdiction patrols" along heavily transited areas near the border with Mexico in an attempt to detect groups of undocumented immigrants in transit. A survey of probable-cause statements used in the prosecution of cases arising out of these patrols reveals a disturbing pattern of justifications for stops.

Deputies often cite minor traffic violations to justify their stops, but their descriptions of these situations include characterizations of these drivers and their passengers as foreign, undesirable, and potentially criminal (Sanchez, 2011). Some probable-cause statements refer to Latino suspects as "smelling like illegal aliens," or cite as reasons for suspicion as "speaking only Spanish" or "looking dirty and soiled." One statement cited "fail[ing] to make eye contact with [the officer] while on the freeway" as a justification for further investigation. These references appear alongside pre-fabricated, boilerplate narratives designed to increase the odds that the probablecause statement will hold up in court (Provine and Sanchez, 2012).

The justifications for stopping and detaining individuals described here smack of ethno-racial profiling and stereotyping that uses physical appearance to make assumptions about legal status and behavior. These practices also suggest that local law enforcement is taking on some of the powers of the Border Patrol, which is not limited by the reasonable-suspicion requirement and has broader latitude in considering ethnic/racial characteristics (US v. Brignoni-Ponce, 1975). The blending effectively removes the 100-mile limit on the more intrusive stops that Border Patrol agents are authorized to conduct and reallocates border-specific federal enforcement powers to the interior of the state of Arizona.

\section{SB 1070}

The 2010 adoption of SB1070, The Support Our Law Enforcement and Safe Neighborhoods Act, cemented the state's reputation as a trendsetter in immigration enforcement. Among its 10 provisions, the most notable is Section $2 b$, requiring that a police officer ascertain the legal status of anyone he or she stops if the officer suspects that person might be undocumented. If suspicions persist, the officer must detain the individual and contact federal immigration authorities. A department's failure to enforce SB1070 is grounds for a citizen-initiated suit for damages. This law expands the powers to stop and search and offers a blueprint for other states to express their determina- 
tion to fight unauthorized immigration by deploying municipal police in the effort. A few other states, including Alabama and Georgia, have followed Arizona's lead.

SB1070 is distinctive among the steady stream of Arizona laws directed at unauthorized immigrants in focusing its requirements on police agencies. The requirement that every police unit in the state actively participate in immigration enforcement was intended to force the hand of city governments and urban police departments that were attempting to be more welcoming toward immigrants by overlooking immigration status when possible. SB1070 thus signaled how a state legislature could override local opposition while forcing the federal government's hand to take a more aggressive role in enforcement.

The political message resonated with the Arizona electorate. Republican politicians in the state had cultivated a sense of crisis about illegal immigration for years, but the rhetoric in this period was particularly lurid, with (false) stories about headless bodies in the desert and other atrocities allegedly produced by Mexican drug cartels and human smugglers. The passage of SB1070 in April 2010 seemed to offer a meaningful response to such criminal activities and resulted in the entire Republican slate being swept into office in statewide elections in November of that year.

SB1070 provoked immediate lawsuits from civil-rights organizations and from the federal government. One of these challenges was adjudicated by the U.S. Supreme Court, which reached a closely divided decision in July 2012. The Court upheld Section $2 \mathrm{~b}$, the law's most controversial provision, while striking down three others (U.S. v. Arizona, 2012). The Court did put two important limits on the almost unfettered discretion of local police, requiring that stops not be prolonged beyond the norm for the offense in question, and requiring federal approval before a suspected unauthorized immigrant could be detained.

In its decision, the Court appears to have attempted to strike a middle ground, reasserting the federal government's plenary power in every aspect of immigration policy, including enforcement, but permitting Arizona a limited role in the process. The problem, critics assert, is that ample room remains for local law enforcement to engage in racial profiling and pretextual stops. These issues provoked renewed efforts to overturn the law's provision allowing local police to question immigration status (ACLU, 2013).

The effort to restrain racial profiling of Latinos in Arizona also continues within the federal government. After years of complaints about racial profiling, federal officials withdrew authority to make immigration arrests from five Arizona jurisdictions, though it left in place their authority to assist the federal government in identifying already-arrested immigrants for possible deportation. ${ }^{2}$ The Justice Department

\footnotetext{
2 The cooperative arrangement grew out of legislation authorizing memoranda of understanding between officials in ICE and local law enforcement agencies. These documents, dubbed "287(g) agreements" after
} 
was also able to claim victory in a case charging Sheriff Arpaio with racial profiling after eight years of litigation (Ortega Melendres et al. v. Arpaio et al., 2013).

It is important to note the specificity of Arizona's efforts. The state is relatively welcoming to refugees and legal immigrants from all over the world. Unauthorized immigration from Mexico, however, has made the state uneasy since territorial days and the damage suffered by citizens and legal permanent residents who are mistaken for illegal immigrants has long been treated as a collateral issue. There are signs, however, that business and political leaders are recognizing that the state's reputation is also at stake. In 2011 state legislators rejected a bill to require teachers to report the immigration status of their students and their parents, a bill to require landlords to check immigration status before leasing, and a proposal for special birth certificates for the babies of unauthorized residents.

\section{ConCLUSION}

Pressure is building for immigration reform at the national level. The inspiration is not a sense of collective guilt about past and current racism in the enforcement of current immigration laws. Rather the impetus comes from the victims of this discrimination, who are speaking out and organizing for legislative reform. Latino immigrants and their supporters are creating significant political pressure for changes that will create legal status for most of the approximately 11 million people currently living in the United States without legal status. This would do much to improve the quality of life for Latino immigrants and their families, but it would not deal a mortal blow to racism in immigration enforcement. It would only close the open wound.

Even with legalization of resident immigrants' status, immigration laws would require enforcement. The mechanisms that have been relied upon in the current push to increase deportations are unreliable and unfair. Enforcing immigration law through appearance-based criteria is inherently racially discriminatory: it will inevitably negatively affect all members of groups that are presumed to have the greatest number of unauthorized immigrants (see, for example, Bowling and Phillips, 2007).

There is no way to eliminate excess stops and surveillance through monitoring or reporting requirements. Law enforcement officers must be free to exercise a wide measure of discretion to be effective in their work. The problem is that whatever

their location in the federal statute, are of two types. "Jail" authorization allows officers involved in booking suspects to handle immigration-related paperwork. "Patrol" authorization provides local officers with the power to make immigration arrests, previously a power reserved to ICE personnel. In 2011, after more than five years of high-volume arrests, Sheriff Arpaio's "patrol" authority was revoked. 
prejudices and stereotypes are prevalent in the general population are likely to be reflected in police work. The effects go beyond those stopped by law enforcement officers, especially when local police are involved. The ability of police and sheriffs to effectively protect immigrants and their neighborhoods is seriously compromised by immigration-enforcement duties, which breed distrust and unwillingness to call the police as a witness or victim of crime. The only solution is to de-escalate the rhetoric about the dangers of unauthorized immigrants living in our midst and to revamp immigration enforcement to focus on concrete evidence of lack of legal status in employment records or other materials. No stop or arrest should occur without some evidence that the law has been broken. This is standard procedure for citizens and legal permanent residents. It should be standard procedure for everyone.

\section{BIBLIOGRAPHY}

(AClu) American Civil Liberties Union

2013 "Valle del Sol v. Whiting et al.: Challenging SB 1070-Arizona's Racial Profiling Law," https://www.aclu.org/immigrants-rights/valle-del-sol-v-whiting-et-al, accessed 8 November 2013.

ANDERSON, B.

1983 Imagined Communities: Reflections on the Origin and Spread of Nationalism, New York, Verso.

\section{BOSNIAK, L.}

2006 The Citizen and the Alien: Dilemmas of Contemporary Membership, Princeton, Princeton University Press.

Bowling, B., and C. Phillips

2007 "Disproportionate and Discriminatory: Reviewing the Evidence on Police Stop and Search," Modern Law Review, vol. 70, no. 6, pp. 936-961.

Brown, M. K.

1988 Working the Street: Police Discretion and the Dilemmas of Reform, New York, Russell Sage.

CAMAYD-Freixas, E.

2008 "Interpreting after the Largest ICE Raid in U.S. History: A Personal Account," 
http: / /graphics8.nytimes.com/images / 2008/07/14/ opinion/14ed-camayd .pdf, accessed November 8, 2013.

Chambliss, W.

1994 "Policing and the Ghetto Underclass," Social Problems, vol. 41, no. 2, 177-94.

Chavez, L. R.

2008 The Latino Threat: Constructing Immigrants, Citizens, and the Nation, Palo Alto, California, Stanford University.

CHIN, G. J.

2005 "Che Chan Ping and Fong Yue Ting: The Origins of Plenary Power," in D. A. Martin and Schuck, eds., Immigration Stories, New York, Foundation Press.

Chiu, B., L. Egyes, P. L. Markowitz, and J. Vasandani

2009 Constitution on ICE: A Report on Immigration Home Raid Operations, New York, Cardozo Immigration Justice Clinic.

CRuz, E. H.

2012 "Unearthing and Confronting the Social Skeletons of Immigration Status in Our Criminal Justice System," in C. E. Kubrin, M. S. Zatz and R. Martínez, eds., Punishing Immigrants: Policy, Politics, and Injustice, New York, New York University Press, pp. 91-112.

DANIELSON, M. S.

2013 "Documented Failures: The Consequences of Immigration Policy on the U.S.-Mexico Border, Nogales, AZ: Kino Border Initiative," http:/ / www.jesuit .org/jesuits/wp-content/uploads / Kino_FULL-REPORT_web.pdf, accessed November 8, 2013.

Decker, S., P. G. Lewis, D. M., Provine, and M. W. VARSANyi

2011 "Immigration and Local Policing in Smaller Municipalities: Results from a National Survey of Law Enforcement Executives," February 18, http: / ccj .asu.edu/research/immigration-research-section/ current-project/immigra tion-and-local-policing-in-smaller-municipalities-results-from-a-national -survey-of-law-enforcement-executives / view, accessed November 8, 2013. 
Doty, R. L.

2010 "SB 1070 and the Banality of Evil," Z Magazine, October 9, http:/ / www .zcommunications.org/sb1070-and-the-banality-of-evil-by-roxanne-doty, accessed July 31, 2011.

gao (General Accounting Office)

2009 "Immigration Enforcement: Better Controls Needed over Program Authorizing State and Local Enforcement of Federal Immigration Laws," U.S. Government Accountability Office, January.

GARDNER, T., and A. KoHLI

2009 "Racial Profiling in the ICE Criminal Alien Program," September 2009 Policy Brief, The Chief Justice Earl Warren Institute on Race, Ethnicity, and Diversity, Berkeley, University of California Law School.

Gladstein, H., A. Lai, J. WAgner, and M. Wishnie

2005 "Blurring the Lines: A Profile of State and Local Police Enforcement of Immigration Law Using the National Crime Information Center Database, 2002-2004," Migration Policy Institute, December.

GomeZ, L.

2007 Manifest Destinies: The Making of the Mexican-American Race, New York, NYU Press.

GonZales, D.

2011 "Senate Bill 1070: 1 Year Later," Arizona Republic, April 23, pp. A1, A 10.

2010 "Poll: Many Say Migrant Debate Stirs Racism," Arizona Republic, August 2, pp. A1 and A4.

GORDON, L.

2001 The Great Arizona Orphan Abduction, Cambridge, Massachusetts, Harvard University Press.

Haddal, C. C.

2010 "Border Security: The Role of the U.S. Border Patrol," Congressional Research Service Report, March 3, www.crs.gov, RL32562. 
Hensley, J. J.

2013 "Maricopa County Jail Leads U.S. in ICE Holds," The Arizona Republic, February 26, http: / / www.azcentral.com/news / articles / 20130225maricopa-county -jail-leads-us-ice-holds.html, accessed March 8, 2013.

HuMAN Rights Watch

2009 Forced Apart (by the Numbers), New York, Human Rights Watch.

ICE (IMMigRation AND CUSTOMS ENFORCEMENT)

2013 "Fact Sheet: ICE Fugitive Operations Program (July 2, 2013)," http: / / www .ice.gov/news / library/factsheets / fugops.htm, accessed November 8, 2013.

KANG, D.S.

2010 "Crossing the Line: The INS and the Federal Regulation of the Mexican Border," in B. Johnson and A. R. Graybill, eds., Bridging National Borders in North America, Durham, Duke University Press, pp. 167-198.

KANSTROOM, D.

2007 Deportation Nation: Outsiders in American History, Cambridge, Massachusetts, Harvard University Press.

Kohli, A., P. L. Markowitz, and L. Chavez

2011 "Secure Communities by the Numbers: An Analysis of Demographics and Due Process," Berkeley, Berkeley Law School, University of California.

MASSEY, D. S.

2007 Categorically Unequal-The American Stratification System, New York, Russell Sage.

Massey, D. S., J. Durand, and N. J. Malone

2002 Beyond Smoke and Mirrors: Mexican Immigration in an Era of Economic Integration, New York, Russell Sage.

MCDOWELl, M., and N. WONDERS

2010 "Keeping Migrants in their Place: Technologies of Control and Racialized Public Space in Arizona," Social Justice, vol. 7, no. 2, pp. 54-72. 
Mendelson, M., S. Strom, and M. Wishnie

2009 "Collateral Damage: An Examination of ICE's Fugitive Operations Program," Migration Policy Institute, February.

Menjivar, C., and O. SALCido

2001 "Immigrant Women and Domestic Violence: Common Experiences in Different Countries," Gender \& Society, vol. 16, no. 6, pp. 898-920.

NeVINS, J.

2002 Operation Gatekeeper and Beyond: The War on "Illegals" and the Remaking of the U.S.-Mexico Boundary, New York, Routledge.

NGAI, M. M.

2004 Impossible Subjects: Illegal Aliens and the Making of Modern America, Princeton, Princeton University Press.

NGuYen, T.

2005 We Are All Suspects Now: Untold Stories from Immigrant Communities after 9/11, Boston, Beacon Press.

OMI, M., and H. WINANT

1994 Racial Formation in the United States: From the 1960s to the 1990s, New York, Routledge.

PARK, J. S. W.

2004 Elusive Citizenship: Immigration, Asian Americans, and the Paradox of Civil Rights, New York, New York University Press.

PAssel, J. S., and D. COHN

2010 U.S. Unauthorized Immigration Flows Are Down Sharply since Mid-decade, Washington, D.C., Pew Research Center.

Provine, D. M.

2012 "Local Immigration Policy and Global Ambitions in Vancouver and Phoenix," in M. Varsanyi, ed., Taking Local Control: Immigration Policy Activism in U.S. Cities and States, Stanford, California, Stanford University Press, pp. 217-238. 
Provine, D. M., and R. D. Doty

2011 "The Criminalization of Immigrants as a Racial Project," Journal of Contemporary Criminal Justice, Special issue: Between Black and White: Theorizing Racial Democracy, Crime, and Justice, vol. 27, no. 3, pp. 261-277.

Provine, D. M., and G. SANCheZ

2012 "Suspecting Immigrants: Exploring Links between Racialized Anxieties and Expanded Police Powers in Arizona," Policing E Society, vol. 21, no. 4, pp. 468-479.

Provine, D. M., M. W. Varsanyi, P. G. Lewis, and S. H. Decker

2012 "Growing Tensions between Civic Membership and Enforcement in the Devolution of Immigration Control," in C.E. Kubrin, M. S. Zatz, and R. Martínez, eds., Punishing Immigrants: Policy, Politics, and Injustice, New York, New York University Press, pp. 42-61.

Romero, M.

2006 "Racial Profiling and Immigration Law Enforcement: Rounding Up of Usual Suspects in the Latino Community," Critical Sociology, vol. 32, nos. 2-3, pp. 447-473.

Romero, M., and M. SERAG

2004 "Violation of Latino Civil Rights Resulting from INS and Local Police's Use of Race, Culture and Class Profiling: The Case of the Chandler Roundup in Arizona," Cleveland State Law Review, vol. 52, no. 1, pp. 75-96.

SANCHEZ, G.

2011 "Border Crossings: Smuggling Operations in the Southwest," unpublished Ph.D. dissertation.

SEMPLE, K.

2011 "Immigrant Detentions Draw International Fire," The New York Times, March 18, http: / www.nytimes.com/2011/03/18/us/18detain-1.html, accessed July 31, 2011.

Shahani, A., and J. Greene

2009 "Local Democracy on Ice: Why State and Local Governments Have No Business in Federal Immigration Law Enforcement," Justice Strategies, February. 
SINEMA, K.

2012 "No Surprises: The Evolution of Anti-immigration Legislation in Arizona," in C. E. Kubrin, M. S. Zatz and R. Martínez, eds., Punishing Immigrants: Policy, Politics, and Injustice, New York, New York University Press, pp. 62-90.

Singer, A., W. S. HARDwick, and C. Brettell, eds.

2008 Twenty-first Century Gateways: Immigrant Incorporation in Suburban America, Washington, D.C., Brookings.

SPAGAT, E.

2013 "US Border Patrol Rejects Curbs on Force," The Boston Globe, November 7, http: / / www.bostonglobe.com/news / nation/2013/11/06/ exclusive-bor der-patrol-rejects-curbs-force/OBfZryfyJ2dLeR2TJeeywM/story.html, accessed November 7, 2013.

TReVizo, Perla

2013 “'Operation Streamline' Takes Hard Line on Illegal Border Crossers," Arizona Daily Star, March 24, http:/ / azstarnet.com/news/local/border/operation -streamline-takes-hard-line-on-illegal-border-crossers / article_35cb6dc545e3-55e5-b471-c1dd2a72bc31.html, accessed February 1, 2014.

\section{UnIVERSITY OF ARIZONA}

2011 The Bisbee Deportation of 1917, http:/ / www.library.arizona.edu/exhibits / bisbee/, accessed July 31, 2011.

VARSANYI, M. W.

2008 "Immigration Policing through the Backdoor: City Ordinances, the 'Right to the City' and the Exclusion of Undocumented Day Laborers," Urban Geography, vol. 29 , no. 1 , pp. 29-52.

ZOLBERG, A. R.

2006 A Nation by Design: Immigration Policy in the Fashioning of America, Cambridge, Massachusetts, Harvard University Press.

ZúÑIGA, V., and R. HERnÁNDEZ LeÓN, eds.

2005 New Destinations: Mexican Immigration in the United States, New York, Russell Sage. 


\section{CASES}

Flores-Figueroa v. US, 556 U.S. 646 (2009).

Ortega Melendres et al. v. Arpaio et al., no. PHX-CV-07-02513 (2013), https: / / www.aclu. org / files / assets / arpaio_decision.pdf, accessed November 8, 2013.

Padilla v. Kentucky, 559 U.S. 356 (2010).

U.S. v. Arizona, 567 US (2012).

US v. Brignoni-Ponce, 422 U.S. 873 (1975). 